\title{
The state and prospects of using Central Russian bee colonies of the "Orlovsky" type
}

\author{
N.N. Grankin, S.N. Bakina*, A.P. Tyapkina, T.V. Fedyaeva, and E.A. Fomina \\ Orel State University n.a. I.S. Turgenev, Orel, Russia
}

\begin{abstract}
. the article presents data on the state and prospects of using the Central Russian bee colonies of the highly productive "Orlovsky" type. The features of the source material for breeding, growth characteristics, productivity for honey and wax of bee colonies of geographically remote populations are presented. The scheme of the breeding process and the results of the evaluation of the main biological and economically useful traits at the stages F1-F6 are presented. The principle of organization and functioning of apiaries of bee colonies of a new type is described. The main features of bee colonies of the bred type and recommendations for their use in the area of the Central Russian bee breed are given. The feedback mechanism in the functioning of apiaries of bee colonies of the bred type is evaluated. The results of the introduction of Central Russian bee colonies and queens of the "Orlovsky" type in the central and northern regions of the Russian Federation are presented.
\end{abstract}

\section{Introduction}

One of the primary tasks of domestic beekeeping has been and remains the preservation of the natural gene pool of honeybees and the rational use of the breeding achievements obtained in recent decades with bee families of the Central Russian, gray mountain Caucasian, Carpathian and Far Eastern breeds [1,2].

Each of the bred types, lines, and interbreed groups, depending on the characteristics of source material, breeding program, honey collection and technological conditions of their use, represents groups of bee colonies defined by number with an increased concentration of highly productive, disease-resistant, with accelerated growth and development, with changes in genotypes that are more or less steadily manifested in the generations since their creation [9].

Approved by the state commission of the Russian Federation "On testing and protection of breeding achievements", the highly productive types "Orlovskiy", "Tatarskiy", "Bashkirskiy" of the Central Russian breed, "Prioksky" on the basis of crossing the Central Russian and gray mountain Caucasian, "Krasnopolyansky" of gray mountain Caucasian, "Maikopskiy" of Carpathian breed are used in their farms and are reproduced for different regions of our country, near and far abroad [3].

The isolated types of the main domestic bee breeds have an increased productivity of honey and wax by $20-40 \%$, should serve as a basis for the development of beekeeping in

* Corresponding autor: lana.88@yandex.ru 
the regions, for the elimination of the chronic shortage of bee colonies, for the full use of the country's honey collection potential and high-quality pollination of entomophilic structures.

The purpose of this article is to discuss one of the variants of breeding and reproduction of Central Russian bees of the "Orlovsky" type.

\section{Materials and methods}

Dark European wood Apis mellifera mellifera L. as a subspecies of the common honeybee in the Russian area known as the Central Russian, makes up to more than $60 \%$ of the total number of bee colonies and is considered the main one in our country.

Differentiated for a number of local populations, the Central Russian bee formed a unique genotypic structure in the post-glacial period, as the basis for high resistance to extreme conditions of the northern border of the species' range, which ensured distribution from Karelia to Eastern Siberia [8].

A comparative assessment of the local groups of the Central Russian bee breed showed its significant polymorphism in Table 1 .

The "Orlovsky" type of Central Russian bee was bred by panmixia of outbreed drones and queens of different geographically remote populations at an isolated point in the SE "Orlovskoye Polesiye" of the Khotynetsky district of the Oryol region (Fig. 1). The spatial isolation radius of the point is 7-9 $\mathrm{km}[5]$.

Table 1. Features of Central Russian bees of local populations

\begin{tabular}{|c|c|c|c|c|c|}
\hline No. & Populations & $\begin{array}{l}\text { Average daily } \\
\text { egg production } \\
\text { of queen bees, } \\
\text { eggs }\end{array}$ & $\begin{array}{l}\begin{array}{l}\text { Bee colonies } \\
\text { mass growth } \\
\text { rate }\end{array} \\
\mathrm{A}=\left(\mathrm{W}_{2^{-}}\right. \\
\left.\mathrm{W}_{1}\right) /\left(\mathrm{t}_{2}-\mathrm{t}_{1}\right)\end{array}$ & $\begin{array}{l}\text { Honey } \\
\text { productivity, } \mathrm{kg}\end{array}$ & $\begin{array}{l}\text { High } \\
\text { productivity, } \\
\text { honeycombs }\end{array}$ \\
\hline 1. & Vologodskaya & 2169 & 4.0 & 75.3 & 7.0 \\
\hline 2. & Orlovskaya & 2020 & 2.9 & 52.1 & 7.7 \\
\hline 3. & Mordovskaya & 1716 & 4.0 & 38.1 & 7.0 \\
\hline 4. & Mariyskaya & 1442 & 2.8 & 34.0 & 6.0 \\
\hline 5. & Bashkirskaya (c.) & 1792 & 3.3 & 41.5 & 8.0 \\
\hline 6. & Bashkirskaya (k.) & 1587 & 1.6 & 40.5 & 7.3 \\
\hline 7. & Bashkirskaya (1.) & 2000 & 4.8 & 40.0 & 8.5 \\
\hline 8. & Tatarskaya & 2178 & 3.4 & 66.3 & 11.7 \\
\hline 9. & Kirovskaya & 1554 & 3.5 & 35.3 & 8.0 \\
\hline 10. & Permskaya & 1767 & 4.1 & 30.0 & 5.0 \\
\hline 11. & Kemerovskaya & 1488 & 3.7 & 38.0 & 6.0 \\
\hline 12. & Gorno-Altayskaya & 1458 & 3.1 & 29.0 & 8.0 \\
\hline 13. & Krasnoyarskaya & 1842 & 5.3 & 42.0 & 8.0 \\
\hline
\end{tabular}

Preserving the original population diversity, in each generation of bee colonies, in accordance with the breeding program, an individual selection was carried out with an assessment of the queens according to progeny quality (Fig.1). 


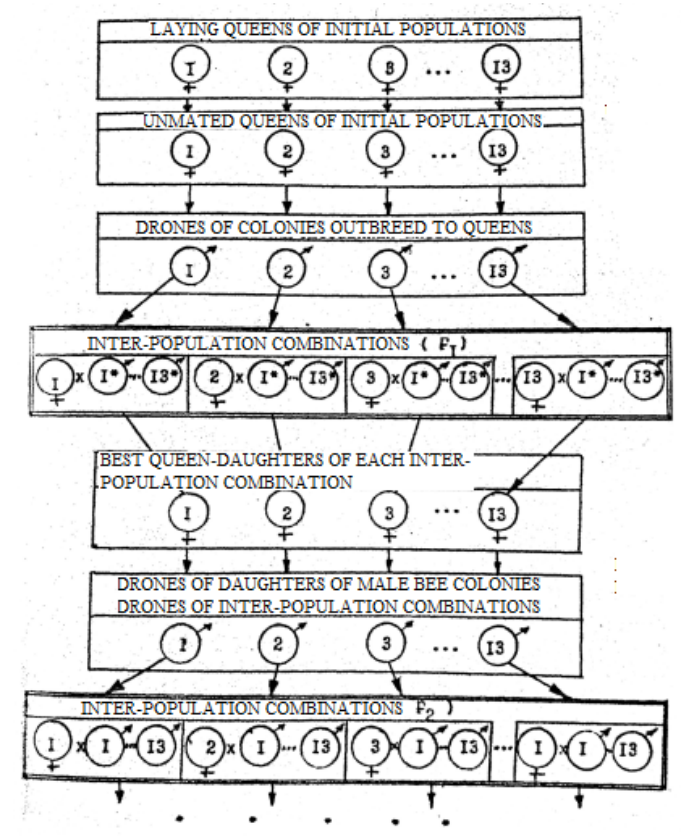

Fig. 1. Breeding scheme of Central Russian bees of the "Orlovsky" type.

\section{Results and discussion}

As the study showed, the progenitress of each generation exceeded the average level of the bred group. The maximum average daily egg production of queen bees was higher by $13.4 \%$, honey productivity of bee colonies - by $33.3 \%$, wax productivity - by $31.2 \%$. For further breeding and selection, the best female and male colonies were taken. [7].

Monitoring studies over six generations of bee family selection indicate a positive effect of the interpopulation combining ability of Central Russian bees in Table 2.

Table 2. Economic and useful traits of bee colonies of the "Orlovsky" type

\begin{tabular}{|l|l|l|l|l|l|l|l|l|l|l|l|}
\hline Features & Initial & $\mathrm{F}_{1}$ & $\mathrm{~F}_{2}$ & $\mathrm{~F}_{3}$ & & $\mathrm{~F}_{4}$ & $\mathrm{~F}_{5}$ & $\mathrm{~F}_{6}$ \\
\cline { 3 - 11 } & group & 1994 & 1995 & 1996 & 1997 & 1998 & 1999 & 2000 & 2001 & 2004 \\
\hline $\begin{array}{l}\text { Maximum } \\
\text { average daily } \\
\text { egg } \\
\text { production of } \\
\text { queen bees, } \\
\text { eggs }\end{array}$ & 1699 & 2176 & 2140 & 2027 & 1976 & 1997 & 2037 & 2210 & 2019 & 1976 \\
\hline In \% & 100 & 128 & 126 & 119 & 116 & 118 & 120 & 130 & 119 & 116 \\
\hline $\begin{array}{l}\text { Henow } \\
\text { productivity, } \\
\text { kg }\end{array}$ & 43.2 & 51,2 & 51.4 & 50.4 & 54.7 & 48.8 & 62.4 & 59 & 51 & 58 \\
\hline In \% & 100 & 119 & 120 & 117 & 127 & 112 & 144 & 137 & 116 & 133 \\
\hline
\end{tabular}

It should be noted that the conditions of bee colonies maintenance and using were identical from year to year. Wintering was carried out in a typical semi-underground winter house with a constant air temperature at the level of $+3-+4^{\circ} \mathrm{C}$ and a relative humidity of $70-80 \%$.

During the season, the apiaries changed their place twice. In May-June, they were moved to the territory of the SE "Orlovskoye Polesie", where such nectariferous plants as raspberry, buckthorn and meadow grasses predominated. Daily deliveries of nectar and 
pollen by bees under favorable conditions and mass flowering of the main nectariferous plants reached $7.5 \mathrm{~kg}$, and the total - up to $100 \mathrm{~kg}$ or more. At the end of June, apiaries were moved to buckwheat crops in the Soskovsky, Uritsky and Orel districts of the region, where in favorable seasons the daily yield of nectar from buckwheat reached $15 \mathrm{~kg}$, and the total up to $130 \mathrm{~kg}$ of honey [6].

Monitoring studies of 9 seasons showed an excess of the average daily egg production of queens by $21 \%$, in contrast to the initial group. Annual queen bees of the F5 progeny laid an average of 2,210 eggs per day, which is the maximum productivity before the main honey collection. Honey productivity of F1-F6 bee colonies in buckwheat nectariferous plants exceeded the level of the initial group trait by an average of $34 \%$, with certain fluctuations depending on weather conditions and crop production practices. The greatest productivity in honey was shown by bee families of F5 progeny with two-year-old queens, which collected $62.4 \mathrm{~kg}$ of honey per colony.

During breeding process, the number of bee colonies of the "Orlovsky" type increased due to the organization of new apiaries, and by the time of submission to the State Commission, it was a group of interconnected and interacting apiaries. The structure of the new type had to meet the requirements that determine its stability at the achieved levels of productivity, the ability to grow and regularly update the queen composition, the ability to impart the properties of record-breaking bee colonies to the entire array of bee colonies of the resulting type, and, in general, to self-regulate within a semi-closed system.

For the first time, the functional, organizational and zootechnical structure of apiaries was developed and successfully implemented in the breeding of the outbred line No. 7 of the Orel population of Central Russian bees in the apiaries of the Orel experimental station of the Research Institute of Beekeeping back in the 70s of the last century [4].

Practical experience has shown its effectiveness in determining the structure of apiaries of the "Orlovsky" type (Fig. 2.).

The apiaries that make up the "Orlovskiy" type specialize in 4 areas in their activities:

1-test apiary, where individual selection of bee colonies is periodically carried out with an assessment of their queens by the quality of progeny, the degree of genotypic diversity for specific moments and the intensity of selection in connection with its purpose is determined.

2-queen bee apiary for the production of unmated queen bees of the bred group, which supplies material both for its own and for apiaries in other regions.

3 and 4-queen bee apiaries for the production of laying queen bees of the selected type. Laying and unmated queen bees are used both for internal purposes: regular updating of the queen composition, formation of new bee colonies and organization of new apiaries, and for development of beekeeping in other regions of the country.

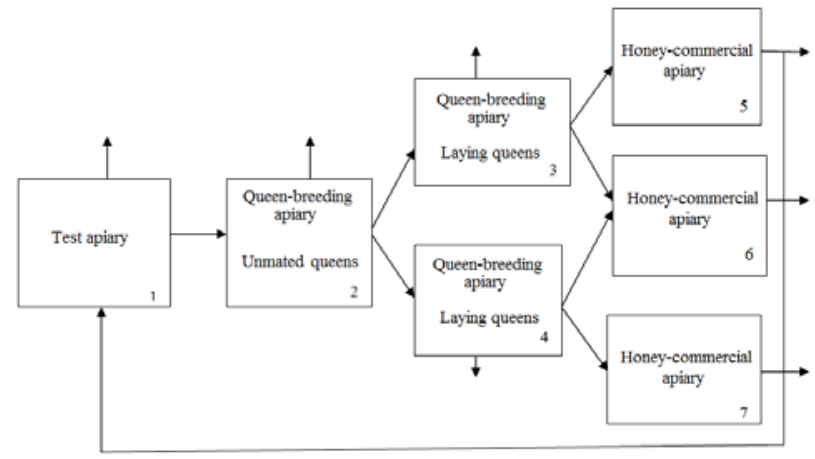

Fig. 2. Specialization of apiaries of the Central Russian bee families of the "Orlovskiy" type» 
The place of production evaluation of the selected material is honey-commercial apiaries 5,6,7. The information obtained at this site gives an idea of the breeding effectiveness. The best bee colonies identified in honey-commercial apiaries in terms of economically useful traits are again transferred to the test apiary to evaluate the queen bees in terms of their progeny quality, analyze the genotypic diversity of the bred traits, and identify highly productive bee colonies for further breeding and reproduction. Feedbacks between the sites serve as a mechanism for self-regulation and self-improvement of the system.

Depending on economic conditions, nectariferous base, market demand for a particular type of beekeeping products, specialization of apiaries of the selected type may change. The adjustable mobility of the structure of the array of bee colonies ensures the stability of the effective functioning of a new type of Central Russian bees.

The most important stage in the effective use of a new type of bee colonies is its introduction into production. Isolated Central Russian bee colonies and queens are actively used in more than 50 regions of the central part of the country, the Urals and Siberia in Table 3.

Table 3. Introduction of Central Russian bee colonies and queens of the "Orlovskiy" type in the central and northern regions of Russia

\begin{tabular}{|c|c|c|c|c|}
\hline \multirow[t]{2}{*}{ Regions } & \multicolumn{2}{|c|}{ 1995-1999 } & \multicolumn{2}{|c|}{$2000-2006$} \\
\hline & $\begin{array}{l}\text { Bee } \\
\text { colonies, } \\
\text { pcs. }\end{array}$ & $\begin{array}{l}\text { Bee } \\
\text { queens, } \\
\text { pcs. }\end{array}$ & $\begin{array}{l}\text { Bee } \\
\text { colonies, } \\
\text { pcs. }\end{array}$ & $\begin{array}{l}\text { Bee } \\
\text { queens, } \\
\text { pcs. }\end{array}$ \\
\hline Vologda & 100 & 1000 & 80 & 800 \\
\hline Leningrad & 70 & 900 & 40 & 1200 \\
\hline Pskov & 90 & 500 & 30 & 800 \\
\hline Kostroma & 50 & 1000 & - & 800 \\
\hline Yaroslavl & 250 & 600 & 100 & 500 \\
\hline Kaluga & 50 & 4500 & 20 & 1000 \\
\hline Bryansk & 140 & 1050 & 200 & 800 \\
\hline Belgorod & 200 & 500 & 40 & 400 \\
\hline Kirov & 80 & 1000 & 100 & 760 \\
\hline Chelyabinsk & 200 & 3000 & 70 & 1100 \\
\hline Perm & 150 & 2000 & 20 & 800 \\
\hline Sverdlovsk & 100 & 500 & 40 & 700 \\
\hline Kurgan & 90 & 300 & 60 & 600 \\
\hline Omsk & 50 & 1500 & - & 800 \\
\hline Tomsk & 150 & 1000 & - & 650 \\
\hline Total & 1770 & 19350 & 780 & 10910 \\
\hline
\end{tabular}

Large apiaries based on the Central Russian bee families of the "Orlovskiy" type were formed in the subsidiary farms of the Magnitogorsk, Starooskolsky, Cherepovets metallurgical plants, with the organization of large apiaries in the Yaroslavl, Kaluga, Leningrad and other regions [10].

The families obtained as a result of breeding should be reproduced and introduced in the regions of their natural range on a large scale.

The biological features of the Central Russian bees correspond to the honey-collection and climatic conditions of the Central forest zone of Russia. Sufficient content of the territory of nature reserves (Darwinskiy, Centralno-Lesnoy, Bryanskiy, National parks Orlovskoye Polesie, Smolenskoye Poozerye, etc.) will actively contribute to the maintenance of the species composition of entomophilic plants and the formation of the food resource of the protected fauna. 


\section{Conclusions}

The polymorphism of Central Russian bees serves as an important reserve for purebred breeding.

Central Russian bee colonies of the "Orlovskiy" type, bred on the basis of geographically remote populations of this breed, have increased winter hardiness and resistance to diseases, intensive growth and effective use of honey collections from buckwheat, linden, cypress and other entomophilic plants are promising for breeding and use in the central and northern regions of Russia.

\section{References}

1. G.A. Avetisyan, Collection of the 25th International Congress on Beekeeping, 74 (1975)

2. G.D. Bilash, Apiakta, 3, 111 (1975)

3. A.V. Borodachev, N.I. Kryvtsov, Vestnik RASKHN, 4, 70 (2000)

4. N.N. Grankin, Organization of apiaries for linear breeding. Beekeeping, 7, 19 (1982)

5. N.N. Grankin, S.N. Bakina, E.A. Fomina, Proceedings of the All-Russian Scientific and Practical Conference "Natural and Humanitarian Sciences in the modern world", 32 (2019)

6. N.N. Grankin, Scientific Notes of the Orel State University. Series: Natural, Technical and Medical Sciences, 4, 102 (2009)

7. N.N. Grankin, A.P. Tyapkina, E.A. Fomina, S.N. Bakina, A.M. Ignatov, Collection of articles of the II All-Russian Scientific and Practical Conference "Natural Resources of the Central region of Russia and their rational use", 51 (2018)

8. N.N. Grankin. Structure of the breed of Central Russian bees. Beekeeping, 5, 19 (1994)

9. A. S. Gurchenko, Central Russian bees in Belarus. Beekeeping, 6, 14 (1981)

10. N.I. Krivtsov, N.N. Grankin, Central Russian bees and their breeding,139 (2004) 